\title{
Virus Nights
}

\author{
Chèle Thorsen
}

Le texte de Chèle Thorsen navigue entre l'incertaine frontière qui sépare le langage et le corps. Comme une inversion de la thérapie freudienne qui consiste à parler, le mot est pour elle quelque chose qui doit être enfermé, qui ne doit pas être exposé à la narration, qui ne doit pas faire l'objet d'un passaige à l'acte. Et ce mouvement en sens contraire de la narration vers le mot enfermé a quelque chose de bon. Les corps de Thorsen se côtoient comme dans un flot de circulation et naviguent dans les routes secondaires, tandis qu'ils poursuivent leurs géographies du désir.

plugging my ears, you open my lips and whisper one word into my mouth. grammar explodes, tracing itself far far down into the depths of me. your hot air and the cure. the word locked in my body. unknown. undiagnosed. you begin me, overindulge me with syllables of pleasure. it's good. it's good. somewhere, car doors open. pills are swallowed. not here. in me everything is unseamed, but a word is stitched inward. you are an arena of gestures and skin, a minor sun. paradise for mirrors. giddy and silent, my fingers scatter south. feed on motors and light. I feel a bell inside you, stalk its ringing, enter its monologue with my tongue, lick its colours, swallow mouthfuls of reds, frost. jerk my head to the side when your stars shoot in all directions. we weave inside each other as in traffic, lifting stomachs, raising hairs, we set each other off, our mouths crammed. the whole city perspiring. we're forgetting our barriers, symptoms, tomorrow's horizon. hooked. we widen the fields of play, your sensual mouth taking me in, zigs, zags, you navigate the side streets, wade through hot water. our wings wetten and we're falling. the oxygen from our hips crackles. we're trying to escape the narration. we enter each other. orgiastic. it's good. it's good. noisily, we stir, we grab, we suppress, we treat, we disguise, we forbid, we deserve. everything decomposes and, skin to skin, we, with a new dexterity, decode the rush and the wait. lying atop one another, we break police line-ups, chocolate, with the slightest brush of our lips. the word locked in. it's good. it's good. 